\title{
PLANTENZIEKTENKUNDIG ONDERZOEK IN AMSTERDAM EN WAGENINGEN
}

1904-1949

DOOR

\author{
Prof. Dr H. M. QUANJER
}

\begin{abstract}
Aan $U$, Mijnheer de President, Curator der Landbouwhogeschool, die menigmaal $U w$ belangstelling in het plantenziektenkundig onderzoek hebt getoond, aan jou, mijn vroww, die het hieraan verbonden lief en leed met mij hebt gedeeld, aan $U$ allen, die aanwezig zijt bij het afscheidscollege tot het houden waarvan de Rector Magnificus mij heeft aitgenodigd, wil ik nu iets meedelen van het werk, dat voor mij een levenstaak is geweest.
\end{abstract}

In het jaar 1904 werd ik benoemd tot assistent aan het Phytopathologisch Laboratorium "WILlie COMMELIN ScHOLTEN" te Amsterdam, een particuliere stichting met Rijkssubsidie. Mijn directeur Professor RIrzema Bos kreeg inzendingen uit het hele land van land-, tuin- en bosbouwers, die zich, dikwijls terecht, ongerust maakten over de een of andere plaag of ziekte in hun gewassen of bomen. Hij gaf meestal zelf advies als er insecten, soms ook als er schimmels in 't spel waren en hij kwam er meer en meer toe het geval aan mij over te reiken wanneer vermoed werd, dat schimmels de schuldigen zouden zijn.

In $1906 \mathrm{kwam}$ het laboratorium W.C.S. onder leiding van Professor WEsTERDIJK, die het woonhuis in Amsterdam spoedig kon verruilen voor een betere werkgelegenheid in Baarn, waar zij de phytopathologie op mycologische grondslag tot ontwikkeling bracht en een aantal phytopathologen heeft opgeleid. Professor RITzEma Bos en ik trokken naar Wageningen, waar de Regering intussen een Institutut voor Phytopathologie aan de Rijks- Hogere Land-, Tuinen Bosbouwschool had verbonden. De stroom van inzendingen werd nog groter. In Amsterdam kon jk er nog eens op uittrekken en op het veld de verwekker vinden 0.a. van de ,draaihartigheid" van kool, een kleine galmugmade, die altijd verdween als men de planten aanraakte en die dus aan het ingezonden materiaal niet te vinden was. In Wageningen werden wij door het toenemende werk meer aan onze standplaats gebonden. Daar stond tegenover dat wij hier meer contact kregen met de beoefenaars van andere landbouwvakken. Dat b.v. een ziekte in de haver, later ,veenkoloniale" ziekte genoemd, niet, zoals tijdens ons verblijf te Amsterdam nog geloofd werd, door een schimmel wordt verwekt, maar het gevolg is van het niet beschikbaar zijn van een der „microëlementen" op alcalisch bemeste grond, is door samenwerking van phytopathologen en bodemkundigen aan het licht gekomen. Nadat HuDig een eindweegs was gevorderd met dit vraagstuk is het in Australië door SAMUEL en PIPER geheel opgelost. Als gevolg van het onderzoek van uit het gehele land ingezonden materiaal kon in vele gevallen teleurstelling worden voorkomen hetgeen voor de betrokkenen van economisch belang was. Maar ook uit sociaal-economisch oogpunt stonden belangen op het spel. Voor ons land nieuwe ziekten en plagen werden spoedig ontdekt en er werden hiertegen, evenals tegen oude bekenden, dikwijls bruikbare adviezen gegeven, die het gehele land ten goede kwamen. 
Het onbevredigende was evenwel, dat het aantal ziekten met onbekende oorzaak, waarover advies gevraagd werd, toenam. Maar ook wanneer de oorzaak bekend was, wisten de boeken, en dus ook wij, er in vele gevallen juist niet genoeg van om de practijk te kunnen helpen. Ofschoon het mij b.v. gelukt was van de "draaihartigheid" van kool en ook van de ,omvalziekte" van dit gewas de verwekkers te kweken en hun pathogeen karakter door infectieproeven te bewijzen, heeft het nog 25 jaar geduurd voor ze effectief konden worden bestreden, hetgeen te danken was aan veel intensiever onderzoek van Dr LEefMaNs en Ir Hus.

Toen wij enige jaren gewerkt hadden in Wageningen, kwamen de Heren VAN Poeteren en Schoevers ons te hulp. De eerste bracht de Plantenziektenkundige Dienst tot ontwikkeling. Deze Dienst, die ontstaan was uit de noodzaak om te voldoen aan de gezondheidseisen, die het buitenland stelt aan de uit Nederland ingevoerde planten en plantendelen, had, totdat VAN POETEREN er zich mee bezig ging houden, weinig te betekenen. Wat deze Dienst is geworden onder zijn leiding is algemeen bekend. De nieuwe directeur Dr BRIEJËR reorganiseert hem op zodanige wijze, dat hij aan de nieuwe na-oorlogse eisen voldoet. De Heer ScHoevers heeft zich met succes in de adviesdienst ingewerkt, hij was een echte plantenarts. Later heeft hij ook getracht het wisselend optreden van plantenplagen en -ziekten tot een opgave van phaenologisch onderzoek te maken. Toen ScHoEvers het advieswerk meer en meer van mij overnam; behoefde ik alleen nog te worden geraadpleegd bij het binnenkomen van ziekten met onbekende oorzaak. Nu kon ik het werk rustiger overzien. Daarbij valt op dat door schimmels, bacteriën, aaltjes of insecten verwekte plantenziekten in 't algemeen een gelocaliseerd karakter hebben, maar dat pathogene verschijnselen, waarin de plant als geheel betrokken is, meestal niet door zulke organismen worden verwekt.

Bij deze laatste bestonden twee mogelijkheden. Zij konden het rechtstreeks gevolg zijn van abnormale omstandigheden van physische of chemische aard zoals de reeds genoemde haverziekte. Daarvan hebben wij later in Nederland voorbeelden leren kennen, o.a. de „onderzeeër"-vorming van aardappelen, welk verschijnsel door WELLENSIEK verklaard kon worden als gevolg van langdurige warmte en droogte tijdens de groei en de overmatige afspruiting, die daarop al vroeg in de winter moet plaats hebben. Wat er dan nog van de pootaardappels overblijft, is na het uitpoten niet meer in staat normale planten voort te brengen; alleen knolletjes kunnen er zich uit ontwikkelen. Tot de kennis van de gebreken overmaatziekten hebben de dames Dr LöHNIS en DE BRUYN en de Heren Dr v. Schreven, in het Zuid-Hollands Glasdistrict Ir vaN Koot en in Zeeland Dr MuLder, bijdragen geleverd.

Maar er is een ziektetype, dat nog veel meer doet denken aan wat wij mensen onder ziekte verstaan. In het begin van deze eeuw kwam dit veel voor in de aardappelcultuur en werd door de kwekers voor "ontaarding" gehouden. Van hoe ernstige aard het was, kan men afleiden uit een Duits geschrift dat tot titel had ,Europa's Kartoffelbau in Gefahr". Maar de geleerden van dat land schreven het - dat was nu eenmaal de geest van de tijd - toe aan schimmels, bacteriën en nematoden. Beurtelings werden tot deze rubrieken behorende organismen als verwekkers dezer ziekten gedoodverfd, alsof er in Duitsland geen ROBERT KOCH had geleefd, alsof niet reeds lang erkend was dat de infectieproef het beslissende is in de phytopathologie.

Aardappelplanten en knollen met dit ziektetype kwamen ook in Wageningen in ontstellend groot aantal binnen. Ik ben nooit in staat geweest zulke wonder- 
lijke dingen te vinden als die collega's beschreven o.a. onder de titel „das pilzlose -Folgestadium der Fusarium-blattrollkrankheit". Na herhaald onderzoek, waarbij ik de afwezigheid van schimmels, bacteriën en aaltjes constateerde, heb ik mij er toe bepaald zieke en gezonde planten te vergelijken, uit- en inwendig te beschrijven en door enting, d.i. de eenvoudigste vorm van infectieproef, vast te stellen, dat er besmetting in het spel was. Zo leerde ik de phloëemnecrose kennen als inwendig kenmerk en de besmettelijkheid als uitwendig waarneembare eigenschap van de bladrolziekte van de aardappel. De mozaiekziekte van dit gewas, die tot dezelfde groep van besmettelijke ziekten bleek te behoren, deed verwantschap vermoeden met de gelijknamige ziekte van tabak, die twintig jaren tevoren door BEIJERINCK aan een „Contagium vivum fluidum" was toegeschreven, een "virus" zoals wij nu zeggen. De bladrolziekte bood echter, in tegenstelling met de mozaiekziekte, weerstand aan alle pogingen om haar met sap over te brengen en zo lag het voor de hand aan te nemen dat er meer ,viren" zijn.

Al spoedig na mijn komst in Wageningen was mij onderwijs in plantenziektenkunde aan de Rijks Hogere Land-, Tuin- en Bosbouwschool toevertrouwd, eerst voor leerlingen, die voor de tropen bestemd waren en later ook voor hen, die de Nederlandse landbouw als studierichting hadden gekozen. Zo kwam ik er toe proeven met hen in te zetten. Schimmels, uit zieke planten geisoleerd, werden op gezonde exemplaren van dezelfde soort losgelaten. Ieder die zulke infectieproeven doet, ondervindt daarbij, dat men er alleen in slaagt ziekten op deze wijze te verwekken, wanneer de plant tot een vatbaar ras behoort, in een vatbaar stadium verkeert en wanneer de ziekteverwekker door regeling van licht, temperatuur, vochtigheid en voeding tot sterke agressie kan worden aangezet. Elke agressor stelt zijn eigen eisen aan het milieu; de een profiteert van gebrek, de ander van overmaat. Een physiologisch krachtige plant is tegen vele van deze organismen bestand. Maar dit geldt minder algemeen voor de eigenlijke, obligate of biotrophe parasieten en de viren, die niet op kunstmatige voedingsbodems kunnen worden gekweekt, ofschoon ook hier vaak een derde factor in 't spel is, die het proces, dat zich afspeelt tussen plant en parasiet in 't nadeel van de eerste beslist.

Het geschiedde in die dagen, dat Dr OORTW1JN BoTJEs te Oostwold een geniale inval had, die hem tot proefnemingen bracht, waarvan de uitslag voor ons land van onschatbare betekenis zou worden. Wanneer de bladrolziekte zich op het veld van zieke op gezonde planten verspreidt, maar een incubatietijd heeft van een jaar, dan moet men dit kunnen vinden door gezonde planten, waarvan de stand ten opzichte van zieke bekend is, afzonderliik na te telen. Deze gedachtengang in proeven omzettend, kreeg hij een positief resultaat. Hij maakte in de volgende jaren een gedeelte van zijn bedrijf dienstbaar aan de grote vooruitgang in de teelt van pootaardappels, die nu mogelijk was geworden en dit ook werd, dank zij de voorlichting aan telers van Ir VERHOEVEN, destijds verbonden aan de Plantenziektenkundige Dienst, van Professor DoRsT, die toen in Friesland werkzaam was en vele anderen; de N.A.K. heeft in deze ontwikkeling een grote rol gespeeld.

Onder de andere, niet minder geniale invallen van Dr OoRTwi jN BOTJEs was er een, die tot infectieproeven leidde, welke beter in Wageningen dan in Oostwold konden worden ondernomen. Zij leerden ons, dat de bladrolziekte door de perzikbladluis wordt verspreid, verklaarden waarom deze ziekte in bepaalde reeksen van jaren volgende op een voorspoedige vlucht dezer diertjes, zo sterk in uitbreiding toeneemt, waarom zij minder kans op uitbreiding heeft in streken met 
een ruw klimaat en nog vele dingen meer, aan de studie waarvan ik mij gaarne geheel had willen wijden, ook omdat door mij was opgemerkt, dat virusziekten voor vele andere voedings- en siergewassen van betekenis zijn.

Intussen vloeiden uit in Wageningen gepubliceerde resultaten uitnodigingerr voort uit landen van de westelijke hemisfeer om er over te komen spreken. Toen begon men in Den Haag te begrijpen, dat het misschien de moeite waard was om niet alleen het werk van de Plantenziektenkundige Dienst, die intussen van de Landbouwhogeschool was afgesplitst, maar ook experimenteel phytopathologisch werk te steunen. Collega VISSER spande zich ervoor, zorgde met de hem eigen voortvarendheid dat het gewenste, geïsoleerd liggende proefveld met laboratorium en viruskassen er kwam; zijn medewerker VAN HOUTEN verzorgde de bouw.

Van het phytopathologisch onderwijs, dat in hoofdzaak van mycologische aard is, zou ik worden vrijgesteld. Reeds was Dr STAHEL te hulp geroepen om dit onderwijs te verzorgen, maar hij trok zich terug omdat er geen hulpmiddelen voor experimenteel werk op dit gebied waren. Wegens vertrek van Professor STAHEL en het feit, dat er toen geen met hem te vergelijken mycologen beschikbaar waren, moest ik wel zorgen dat er virologen en mycologen kwamen. Ik meende niet beter te kunnen doen dan een tweetal aan de Hogeschool aangestelde plantkundigen, wier aantal later verdubbeld werd en enkele op de voorgrond tredende studenten de gelegenheid te geven zich tot mycoloog, viroloog of nematoloog te doen ontwikkelen. Het was een grote vooruitgang, dat, na het aftreden van Professor RitzEMA Bos, het onderwijs en experimenteel onderzoek op entomologisch gebied tengevolge van de benoeming van Professor ROEPKE tot hun recht konden komen. De ontdekking dat de jepenspintkevers de iepenziekte overbrengen, was een der resultaten van de Wageningse entomologen. Wat verder op dat gebied is verricht te bespreken, hoort niet tot mijn taak. Wel bleef, in overleg met Prof. ROEPKE, de studie der nematoden tot mijn afdeling behoren.

De hulpmiddelen, die ik had gekregen voor het onderzoek der virusziekten van de aardappelen moest ik nu ook aan mycologisch werk dienstbaar maken, zoals $U$ nog steeds kunt opmaken uit de naam van het laboratorium "voor Mycologie en Aardappelonderzoek". Dat er ondanks het feit, dat de ruimte hier niet op berekend was, toch enige resultaten op drieërlei gebied zijn verkregen, is te danken aan de onderzoekers zelf. Van deze resultaten worden er hier, zij het onvolledig, enkele meegedeeld, waarbij eerst die welke op mycologisch, dan die welke op virologisch en tenslotte die welke op nematologisch terrein liggen aan de beurt komen.

Mej. H. L. G. DE BruYn bewijst met haar grondleggend werk over de Phytophthora van de aardappel grote diensten aan het Instituut voor Veredeling van Landbouwgewassen. Zij heeft bovendien ontdekt wat de "derde" factor is, die leidt tot het afsterven van de bloemknoppen der Aalsmeerse trekseringen. Phytophthora syringae is elk jaar aanwezig, maar alleen wanneer de herfst overmatig vochtig is, dringt deze zwam van de bladeren via de schors tot de knoppen door, juist in een periode, waarin de schors zich niet verweren kan.

Bij de studie van een voor de boon pathogene schimmel van het geslacht Gloeosporium was reeds een mijner eerste promovendi, Dr H. R. A. Muller, eigenaardige aanpassingsverschijnselen op 't spoor gekomen. Ook op dit voor de phytopathologie belangrijke aanpassingsvraagstuk heeft Mej. DE BRUYN bij haar Phytophthora-studie nieuw licht laten schijnen. 
Pas meer dan tien jaar na de oprichting van het voor de studie van virusziekten ingericht gebouw gelukte het er een kas aan toe te voegen, waarin infectieproeven kunnen worden genomen bij regelbare temperatuur, vochtigheid en licht. Toen de Inspecteur van het Landbouwonderwijs, onze tegenwoordige President-Curator, er zich voorspande, kon de kas, volgens het ontwerp van Dr OORT, gebouwd worden. Hier kon de derde factor, die bij zoveel plantenziekten beslissend is, worden bestudeerd. De inrichting van deze kas heeft, eyenals die van het laboratorium, gedurende de bezetting zeer geleden. Dat wij er intussen weer intensief gebruik van maken is vooral te danken aan de vindingrijkheid en technische bekwaamheid van onze medewerker BoEkHORST.

Onder de voor de Nederlandse veredelaars belangrijke resultaten verdienen die van Dr OORT een speciale vermelding. Hij heeft o.a. door toepassing van door hem uitgedachte infectieproeven de kennis der roest- en stuifbrandziekten van tarwe en gerst verrijkt. Op processen, die zich tussen tarwerassen en rassen van deze parasieten afspelen, hebben wij, als gevolg van dit werk, een goede kijk gekregen. De vatbaarheid kan in verschillende graden aanwezig zijn maar van aanpassing is hier geen sprake; wel van een gevecht tussen plant en agressor op leven en dood. Voor de veredelaars van granen, vlas, klaver, bonen, tomaten, asperges en andere land- en tuinbouwgewassen is de medewerking van phytopathologen onmisbaar geworden, nu wij weten, dat bij de roest- en brandzwammen en andere parasieten rassen voorkomen, die van elkaar verschillen in de plantenrassen, waaraan zij de voorkeur geven. De opsporing van rassen van voor Nederlandse cultuurgewassen pathogene schimmels en viren en van methoden om de vatbaarheid er voor te bepalen, begint onder leiding van de Hogeschoolphytopathologen en hen, die hier gastvrijheid genieten, van betekenis te worden. In dit verband moge ook worden gewezen op Dr GRosJEAN's werk, dat o.a. ten doel heeft voor loodglans onvatbare rassen van pruimen te winnen en Dr GoosSENS waarnemingen over vatbaarheid van erwtenrassen voor een Fusarium, die nieuw schijnt te zijn voor Nederland.

Thans dienen, ook al weer onvolledig, enkele resultaten van de studie der virusziekten te worden vermeld. In de student THUNo vond ik jemand, die door physiologisch onderzoek bevestigde, dat het primaire bij de bladrolziekte is het in de zeefvaten werkzame virus en dat verschuiving der enzymatische functies maar een verschijnsel is van de tweede of derde rang; dit was het onderwerp van zijn proefschrift. Een ander proefschrift, dat van Dr ELZE, bracht nadere gegevens over de rol, die de perzikbladluis speelt en stelde vast, dat het virus der bladrolziekte in een obligate verhouding staat tot de luis. Min of meer sluit zich hier ook bij aan het vrij wat later verschenen proefschrift van Dr VAN SCHREVEN, dat gewijd is aan de physiogene ziekten van de aardappelplant, die destijds met de virusziekten werden verward, en de studiën van Dr v. D. LEK en Dr v. D. MEER over een houtvatenziekte, die eveneens behoorde tot de verschijnselen, die er mee verward zijn geworden.

Het was mij intussen gebleken dat de virusziekten, waarmee de aardappelcultuur ook in Nederland te kampen heeft, bijna even talrijk zijn als de door schimmels verwekte ziekten en dat zij in de wijze van infectie, in de herkomst van het virus en in de anatomische verschijnselen waarmee gevoelige rassen er op reageren, zeer verschillend zijn. Het onderzoek moest dus sterk worden uitgebreid; ik was toen zo gelukkig in de student, nu Ir RozENDAAL, iemand te vinden, die zicit tot deze studie bijzonder voelde aangetrokken. Hij heeft hierover reeds enkele 
kleinere publicaties het licht doen zien, maar de uitgave van het gehele werk is vertraagd in verband met de grote omvang, die het heeft aangenomen.

Om de virusziekten van de aardappel groeperen zich in onze studiën die van biet, tabak, peulvruchten, aardbei en steenvruchten. Nadat door mij in de kennis der bietenziekten enige orde was gebracht, konden van de "vergelingsziekte" door de Belg Ir RoLAND, die enige zomers in Wageningen werkte, en onze oudleerling VAN SCHREVEN in Bergen op Zoom een paar bladluis-soorten als vectoren worden aangewezen. Daarna is dit werk geheel door het Instituut te Bergen op Zoom overgenomen, waar Dr HARTSUIJKER o.a. heeft aangetoond van hoe groot belang voederbietkuilen als infectiebron zijn. Aan de studie van virusziekten heeft tijdens zijn verlof Professor Thung meegewerkt, terwij! Ir HuBbELING en $\mathrm{Ir}$ v. D. WANT ons de infectiebronnen van bonenviren nader hebben leren kennen. Deze zijn van zeer verschillende aard. Sommige viren zijn specialisten, andere gaan van de wilde flora op de cultuurplanten over, weer andere infecteren van de grond uit en deze laatste zijn nog in vele opzichten raadselachtig, al zijn er dan ook reeds electronenfoto's van genomen. Samenwerking van Ir RozendaAl en Ir v. D. WANT heeft reeds geleerd, dat zowel de aardappel als de tabak vatbaar zijn voor infectie van een dezer viren.

$\mathrm{Nu}$ Dr DE FLuITER het entomologisch gedeelte van Dr KLINKENBERG'S onderzoek over de aardbeiviren op zich genomen heeft, kunnen wij ook daarvan resultaten verwachten; de medewerking van de Heer HILLE RIS LAMBERS op 't gebied van de systematiek der vectoren is ons eveneens welkom. Er moet evenwel nog veel meer worden gedaan zal het virologisch onderzoek voldoen aan de rechtmatige eisen, die de landbouw, de groenteteelt, de teelt van groot en klein ooft en de sierteelt mogen stellen in een land, dat op dit gebied in de eerste rijen heeft gestaan.

Voor ik van het virologisch onderzoek afstap, wil ik memoreren dat ook $\mathrm{Dr}$ BAWDEN aan het Rothamsted Experimental Station en Professor VAN SLOGTEREN te Lisse ons nu en dan hebben geholpen.

Toen in 1923 het tegenwoordig.laboratorium en proefveld in gebruik genomen werd, kwam ik in aanraking met een vraagstuk op nematologisch gebied. Het laboratorium is gebouwd op gescheurd grasland in de Gelderse vallei, waar ik een ongespecialiseerd stengelaaltje vond in witte klaver, pinksterbloem en boterbloem. Dit ging op tal van cultuurplanten, o.a. aardappel over, in tegenstelling met het gespecialiseerde stengelaaltje, dat ziekte in cultuurgewassen als hyacinth en narcis verwekt. Enkele jaren later werd ik weer op andere wijze in het Nematoden-vraagstuk betrokken. $U$ wilt mij wel een korte uiteenzetting over besmetting en zuivering van de grond toestaan als inleiding tot deze kwestie, die tot een zeer intensief onderzoek van Ir SEINHORST geleid heeft, een onderzoek over "reup" in de rogge, dat nieuw licht werpt op de derde factor, die hier in 't spel is. Zijn werk zal over niet te lange tijd worden gepubliceerd; ik wil mij er daarom toe bepalen het kort in te leiden.

Een steeds grotere betekenis voor de gezondheidstoestand der cultuurplanten krijgen de pathogenen, die van de grond uit de plant besmetten: viren, schimmels, aaltjes en insecten. Want naarmate de levensstandaard stijgt en de bevolking groeit, moet er meer voortgebracht worden, terwijl voor land-, tuin- en bosbouw steeds minder grond beschikbaar is. De neiging bestaat om te dikwijls met hetzelfde productieve voedingsgewas op dezelfde grond terug te komen. Het ontbreekt niet aan profeten, die voorspellen, dat er een catastrophe moet volgen op 
de geforceerde cultuur, het overmatig gebruik van kunstmest en het verlies aan organische stof. Inderdaad gaan in de moderne samenleving kapitalen aan afvalstoffen verloren en men kan instemmen met de propagandisten voor het behoud daarvan en het terugvoeren aan de grond in verschillende vorm o.a. van compost. Maar de voorspelling dat alle plantenziekten als gevolg van afschaffing van minerale en het gebruik van organische mest zouden verdwijnen, moet tot teleurstelling leiden. Erkend moet worden, dat sommige physiogene ziekten op deze wijze tot zekere graad kunnen worden vermeden. Ook leert de ervaring in de nieuwe Zuiderzeepolders, dat de tarwehalmdoder, die al spoedig na het in gebruik nemen van het land in grote hevigheid optrad, later als de bodem rijker is aan organische stof, verdwijnt, althans op de zwaardere grond. Ook heeft Ir CLEveringa aangetoond, dat de ,reup" in de rogge in belangrijke mate kan worden onschadelijk gemaakt door verbetering van de bodemstructuur. Verder zijn er aanwijzingen, dat bepaalde tussenculturen de zuivering van de grond versnellen; lucerne en rogge hebben een dergelijk effect ten opzichte van aardappelschurft, sojaboon ten opzichte van een bepaald type van wortelaantasting van aardbei. Deze ervaringen hebben tot intensiever onderzoek geleid, waarin zowel microbiologen als phytopathologen betrokken zijn. Ir SEINHORST houdt zich te Wageningen met dit vraagstuk bezig in verband met het stengelaaltje en komt tot resultaten, die Ir CLEVERINGA's ervaring ten dele verklaren. Dr KLINKENBERG is begonnen met het onderzoek van aardbeiziekten die verwekt worden door schimmels, die van de grond uit infecteren. Of dergelijk werk evenwel ook zal kunnen leiden tot het vinden van middelen tot sneller zuivering van de grond van aardappel- of bietenmoeheid is zeer de vraag; de eieren toch van de hierbij werkzame soorten van het wortelaaltjesgeslacht Heterodera zijn in hun "cysten" goed beschermd. Men moet zich derhalve houden aan de periode, die volgens wettelijk voorschrift tussen twee achtereenvolgende beplantingen van dezelfde grond met aardappelen moet verlopen; waar de besmetting reeds aan 't licht is getreden moeten ernstiger maatregelen worden genomen. Toch moet men het onderzoek van de strijd, die zich in de grond afspeelt tussen de verwekkers van ziekten en de andere bodemorganismen met kracht voortzetten om middelen te vinden, die de nuttige bodembewoners een voorsprong kunnen geven. Of met chemische /middelen een dergelijk effect te verkrijgen is zonder dat er op de duur schadelijke gevolgen uit voortvloeien, moet eveneens worden onderzocht.

Het phytopathologisch onderzoek, dat 45 jaar geleden door twee personen op vrij primitieve wijze werd verricht, is uitgegroeid tot een intensieve studie van specialisten, die goede hulpmiddelen hebben en er nog meer moeten hebben. Zij zijn verbonden aan verschillende instellingen waarvan de belangrijkste gelegen zijn te Wageningen, Baarn, Lisse, Bergen op Zoom, Naaldwijk, Aalsmeer en Venlo, terwijl ook aan sommige Universieiten en proeftuinen entomologen en phyto. pathologen werkzaam zijn. Mijn eerste werk, het advies geven, wordt nu grotendeels verricht door de Land- en Tuinbouwvoorlichtingsdiensten, wier deskundigen op dit gebied leiding ontvangen van de consulenten Ir VERHOEVEN en Ir Hus. Gevallen, waarover twijfel bestaat, worden bij de Plantenziektenkundige Dienst gebracht, die zich zo nodig met het Hogeschool-Instituut in verbinding stelt. Daar de Hogeschool-entomologen en -phytopathologen uit de aard der zaak op het fundamenteel onderzoek en het onderwijs zijn aangewezen en het aantal plantenziekten, die men op grond van de bestaande kennis niet kan voorkothen of bestrijden, vooral in de Tuinbouw, zo groot is, heeft de Hogeschool nu reeds 
aan een achttal phytopathologen gastvrijheid verleend, maar deze zullen met hen, die aan Universiteiten, proeftuinen en elders werkzaam zijn, verenigd worden in een nieuw Instituut voor Plantenziektenkundig onderzoek, dat, ter instandhouding van de samenwerking, wordt opgericht op het terrein van het Laboratorium voor Mycologie en Aardappelonderzoek van het Hogeschool-Instituut. Tot de oprichting hiervan heeft de Directeur van de Tuinbouw, Ir v. D. PLASSCHE, de stoot gegeven. Ook op anderewijze kan een band gelegd worden tussen de Hogeschool en het I.P.O., want zij horen biologisch bij elkaar al schijnt het dan ook uit administratief oogpunt voor de Regering gemakkelijker te zijn ze afzonderlijk te beheren.

Het verrichten van onderzoek en het geven van leiding daarbij brengt zijn eigenaardige teleurstellingen en vreugden mee. Soms geraken wij op een dood spoor, maar bij volhouden en verder werken vinden wij toch ook dikwijls de goede weg. Het contact met vakgenoten en practici draagt daartoe bij. Ook heb ik dikwijls ondervonden het heilzaam effect van onderwijs te moeten geven. Bij de voorbereiding daartoe moet men resultaten van onderzoek in synthetisch verband zien, hetgeen soms nieuwe perspectieven opent voor de oplossing van problemen, waar men mee worstelt.

Zo nu en dan hebben onze Hogeschool-phytopathologen en zij, die er gastvrijheid genieten, hun belangstelling in het onderwijs getoond of mij er bij geholpen. Onder Dr VAN VloTEN's leiding was er reeds groot enthousiasme voor de practica; dit is er bij zijn opvolgster Dr KERLINo niet minder op geworden. Dr VAN VLOTEN zet nu zijn werk over de biologie van boomparasieten en de biologische bestrijding daarvan aan het Bosbouwproefstation voort. Maar wij willen ook deze band niet doen verslappen. Dr KERLING is bezig erwtenziekten, die wij reeds kenden, van een nieuwe kant te belichten en laat studenten daaraan meewerken. Ons onderwijs is er op gericht hen te leren van parasieten en viren juist zoveel meer te weten te komen als nodig is om ze van hun wandaden te kunnen afhouden. Ook op dit gebied geldt: Kleine oorzaken grote gevolgen! De hevigheid waarmee de vergelingsziekte der bieten optreedt of waarmee Phytophthora en sommige viren de aardappels teisteren had verminderd kunnen worden door zorgvuldiger reiniging der bewaarplaatsen van voederbieten en van eet- en pootaardappels en wie een dag verzuim pleegt bij het spuiten zijner vruchtbomen, kan het gehele jaar daarvan de schadelijke gevolgen ondervinden.

Onderzoek levert de bouwstenen. Het gebouw der wetenschap wordt er uit opgetrokken, hetgeen wij in ons onderwijs beogen. Voor mij is het een vreugde geweest nu en dan te hebben kunnen meewerken aan het grote doel, dat ons onderzoek en onderwijs nastreeft: de gezondheidstoestand der cultuurplanten en daarmee de vruchtbaarheid van ons land te bevorderen.

Ik kan echter dit afscheidscollege niet beëindigen zonder te gedenken de goede geest en de hulp, die ik steeds heb ondervonden in het laboratorium van allen, die er op wetenschappelijk, technisch en administrat fef gebied werkzaam zijn, en van hen, die in de kassen en op de proefvelden dagelijks onder leiding van de tuinchef $Z_{A N D E R}$ arbeid verrichten. $Z \mathrm{ij}$, die daarbij "getrouw zijn in ' $t$ minste, zijn ook in ' $t$ grote getrouw'. Zij allen leveren, door op duizend kleinigheden te letten, hun bijdrage in de bevordering van het grote belang, dat ons werk voor Nederland heeft. 